\title{
DAMPAK PENANGKAPAN TERHADAP EKOSISTEM: LANDASAN PENGELOLAAN PERIKANAN BERKELANJUTAN
}

Impacts of Fishing on Ecosystem: Basis of Sustainable Fisheries Management

\author{
Oleh: \\ Am Azbas Taurusman ${ }^{1,3 *}$, Budy Wiryawan ${ }^{1}$, Besweni $^{2}$, Isdahartati $^{3}$ \\ ${ }^{1}$ Departemen Pemanfaatan Sumberdaya Perikanan, \\ Fakultas Perikanan dan Ilmu Kelautan, IPB University, \\ Bogor, Indonesia \\ ${ }^{2}$ Direktorat Pengelolaan Sumberdaya Ikan, Kementerian \\ Kelautan dan Perikanan, Jakarta \\ ${ }^{3}$ Pusat Kajian Sumberdaya Pesisir dan Lautan, Lembaga \\ Penelitian dan Pengabdian pada Masyarakat, IPB University, \\ Bogor, Indonesia \\ *Korespondensi penulis: azbas@apps.ipb.ac.id
}

\begin{abstract}
ABSTRAK
Kegiatan penangkapan berdampak langsung dan tidak langsung terhadap ekosistem secara dinamis (spasial dan temporal). Perikanan tangkap harus dikelola pada batas yang memberikan dampak yang dapat ditoleransi oleh ekosistem, merupakan prinsip pertama dalam pengelolaan perikanan dengan pendekatan ekosistem (EAFM). Ekosistem merupakan unit organisasi biologi dimana terjadi hubungan fungsional antara komponen-komponen biotik dan lingkungan abiotiknya pada suatu area tertentu (ecological boundary). Penangkapan berdampak terhadap ikan target, non-target (bycatch), serta habitat (lingkungan), yang diindikasikan oleh degradasi populasi (kematian) ikan target dan nontarget, degradasi (kerusakan) fisik habitat, dan pencemaran lingkungan perairan. Pada gilirannya akan mengakibatkan terjadi degradasi dinamis struktur (jumlah jenis, kelimpahan, biomassa) dan fungsi ekosistem (reproduksi dan rantai makanan). Intensitas dampak penangkapan ditentukan oleh karakteristik kegiatan penangkapan dan kondisi sumberdaya ikan. Suatu analisis terintegrasi dengan memperhitungkan parameter-parameter tersebut diperlukan dalam studi dampak penangkapan terhadap ekosistem. Dalam kerangka EAFM terdapat solusi teknologi dan manajemen untuk mengatasi dampak penangkapan yakni: perbaikan teknologi, pengendalian input-output, manipulasi ekosistem, dan pengelolaan berbasis hak (right-based).
\end{abstract}

Kata kunci: EAFM, dampak penangkapan, perikanan berkelanjutan, struktur-fungsi ekosistem

\section{ABSTRACT}

Fishing has direct and indirect impacts on the ecosystem in dynamically spatial and temporal. Fishery should be managed to limits their impact on the ecosystem to the extent possible, which is the first principle in Ecosystem Approach to Fisheries Management (EAFM). Ecosystem is a unit of biological organization where there is a functional relationship between biotic components and their abiotic environment in a certain area (ecological boundary). Fishing activities, widely consider have impacts on target fish, non-target (bycatch), and habitat (environment) which are indicated by population degradation (mortality) of target and non-target fishes, degradation (damage) of physical habitat, and pollution of the aquatic environment. It is, in turn, will result degradation of the structure (number of species, abundance, biomass) and functioning of the ecosystem (reproduction and the food chain) dinamically. Intensity of fishing impact is determined by characteristics of both fishing activity, and condition of fish resources. An integrated analysis that taking into account these parameters is 
required in the study of fishing impact on ecosystems. Within the EAFM framework, there are technology and management solutions to address the impacts of fishing on ecosystem, namely: technology improvement, input-output control, ecosystem manipulation, and right-based management.

Key words: EAFM, ecosystem structure-functioning, fishing impact, sustainable fisheries

\section{PENDAHULUAN}

Kegiatan penangkapan berdampak langsung dan tidak langsung terhadap ekosistem secara dinamis, spasial dan temporal. Penangkapan berpengaruh pada semua tingkatan organisasi biologi dari individu hingga populasi, karakteristik demografi dan genetik juga komunitas dan ekosistem, termasuk struktur trofik dan aliran energi (Pauly et al. 1998, Jennings et al. 2001, Stergiou et al. 2007). Ekosistem merupakan unit organisasi biologi dimana terjadi hubungan fungsional antara komponen-komponen biotik dan lingkungan abiotiknya pada suatu area tertentu (ecological boundary). Sehingga dapat diklasifikasikan pada kajian ini penangkapan berdampak terhadap ikan target, non-target (bycatch), serta habitat (lingkungan).

Dampak penangkapan terhadap ekosistem telah disadari sejak lama, misalnya dampak trawl terhadap lingkungan bentik telah disadari dan dikembangkan teknologi antisipasinya sejak era 1940an, dan studi dampak penangkapan terhadap non-target telah dilakukan oleh Graham tahun 1955 dan ICES tahun 1970-an (Kaiser dan Groot 2000). Namun studi dampak penangkapan terhadap ekosistem mulai berkembang pesat sejak era 1990-an seiring dengan mulai terjadinya trend penurunan hasil tangkapan ikan global (Jennings dan Keiser 1998). Berdasarkan norma CCRF (1992) dampak penangkapan disepakati dan kemudian diimplementasikan melalui Pengelolaan Perikanan dengan Pendekatan Ekosistem (ecosystem approach to fisheries management), FAO (2003). Prinsip pertama EAFM adalah perikanan harus dikelola pada batas yang memberikan dampak yang dapat ditoleransi oleh ekosistem. Berdasarkan prinsip ini maka implementasi EAFM dalam rangka mewujudkan perikanan berkelanjutan harus mengintegrasikan dampak penangkapan dalam perencanaan pengelolaan perikanan. Jika tidak dampak penangkapan akan berimplikasi tidak hanya merugikan secara ekologis, namun pada gilirannya akan merugikan secara ekonomis dan sosial. Bahkan indikator dampak penangkapan (trophic level based indicator) dikenal sebagai 'Marine Trophic Index' telah ditetapkan sebagai salah satu indikator kunci dalam pengukur perubahan diversitas oleh CBD (the Conference of the Parties to the Convention on Biological Diversity).

Studi tentang dampak penangkapan terhadap ekosistem secara terpadu di Indonesia masih terbatas (e.g. Taurusman 2011, Almodhar et al. 2013, Taurusman et al. 2018). Sementara itu pemahaman tentang konsep ini sangat diperlukan sebagai input utama perumusan pengelolaan perikanan, seperti 'Rencana Pengelolaan Perikanan dan Strategi Pemanfaatan' (harvest strategy) perikanan yang saat ini sedang diimplementasikan oleh Kementerian Kelautan dan Perikanan bersama stakeholders perikanan lainnya. Oleh karena itu, pemahaman tentang konsep dampak penangkapan terhadap ekosistem ini perlu terus didiskusikan secara ilmiah sebagai landasan pengelolaan perikanan berkelanjutan.

\section{METODE PENELITIAN}

Kajian ini dilakukan dengan metode analisis dan review terhadap referensi dan penelitian terkini terkait konsep dampak penangkapan ikan terhadap ekosistem dan pengelolaan perikanan dengan pendekatan ekosistem (EAFM). Hasil diskusi dengan berbagai pihak terutama akademisi dan pemerintah sebagai otoritas pengelola perikanan dalam merumuskan pengelolaan perikanan berkelanjutan oleh penulis utama khususnya sejak tahun 2009 hingga saat ini, menjadi basis dalam melakukan kajian ini. Secara sistimatis analisis disusun berupa perkembangan keilmuan dan penting 
kajian ini sebagai basis pengelolaan perikanan; konsep dampak penangkapan terhadap ekosistem; faktor yang menentukan besarnya dampak; dan solusi teknologi serta manajemen untuk mengatasi dampak penangkapan terhadap ekosistem.

\section{HASIL DAN PEMBAHASAN}

\section{Konsep Dampak Penangkapan Ikan Terhadap Ekosistem}

Kegiatan penangkapan ikan akan mempengaruhi ketersediaan dan keberlanjutan ikan yang menjadi target tangkapan, juga sumberdaya ikan lainnya yang bukan menjadi target tangkapan, serta berdampak terhadap habitat dan lingkungan perairan. Secara sistematis konsep dampak penangkapan terhadap ekosistem disajikan pada Gambar 1.

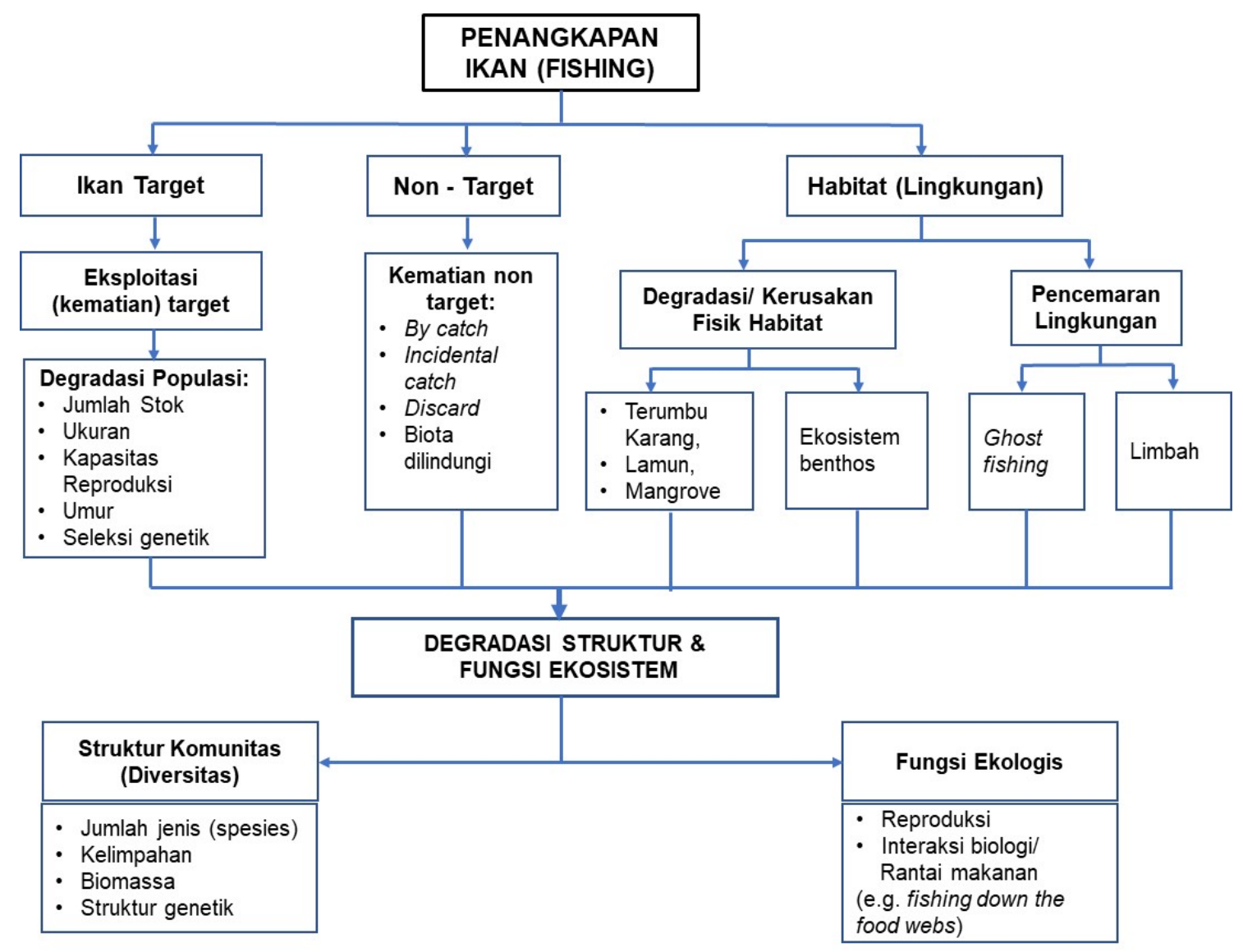

Gambar 1 Konsep Dampak Penangkapan Ikan terhadap Ekosistem

\section{Ikan target tangkapan}

Penangkapan ikan berdampak terhadap sumberdaya ikan target. Akibat eksploitasi ikan target tangkapan, maka akan terjadi kematian akibat penangkapan (fishing mortality), yang berdampak luas terhadap populasi ikan target. Hal ini diindikasikan dengan berbagai parameter populasi, seperti penurunan jumlah spesies, kelimpahan individu, serta keragaman jenis. Pada spesies target tertentu, penangkapan mengakibatkan penurunan jumlah stok bahkan overfishing, penurunan kapasitas reproduksi (spawning potential), pertumbuhan dan maturasi. Lebih lanjut penangkapan mengakibatkan modifikasi struktur umur, rasio kelamin, genetik dan komposisi sumberdaya ikan target serta asosiasi jenis dan yang terkait dengannya. Oleh karena itu, studi tentang dampak penangkapan terhadap ikan target, parameter-parameter tersebut digunakan untuk mengevaluasi besarnya dampak pada suatu sumberdaya ikan tertentu. 


\section{Tangkapan non-target (bycatch)}

Sebagian besar kegiatan penangkapan bersifat tidak cukup selektif hanya untuk mengeksploitasi ikan target. Sehingga tertangkap juga jenis-jenis ikan atau biota lainnya yang bukan target atau bukan ukuran yang diinginkan, hal ini dikenal sebagai bycatch (hasil tangkapan sampingan). Selain ikan, pada bycatch terdapat biota yang dilindungi seperti penyu, lumba-lumba, beberapa jenis hiu dan pari yang dilindungi, bahkan burung laut. Sekitar 27 juta ton bycatch dibuang setiap tahun, data FAO tahun 1990-an (FAO 1997). Selanjutnya dilaporkan bahwa perikanan udang dengan menggunakan trawl penghasil bycatch terbesar, rata-rata global 5 kali bobot udang tangkapan (bycatch rasio $5: 1$ ). Bahkan pada trawl udang di perairan tropis mencapai 20 kali bobot udang tangkapan. Sebagian hasil tangkapan sampingan ini dimanfaatkan dan sebagian lagi dibuang sebagai discard bersama limbah lainnya dari kegiatan penangkapan ke perairan. Kematian biota akibat bycatch ini merugikan secara ekonomis dan ekologis.

\section{Habitat (lingkungan) sumberdaya ikan}

Penangkapan ikan dapat merusak habitat sumberdaya ikan karena operasional suatu alat tangkap atau penerapan suatu teknik penangkapan. Penangkapan ikan ekor kuning dengan operasional alat tangkap 'moroami' secara nyata telah merusak terumbu karang sebagai habitat penting ikan. Operasional alat tangkap yang ditarik untuk menangkap ikan di dasar perairan seperti trawl dasar dan garuk telah dilaporkan secara luas berdampak besar terhadap kerusakan ekosistem benthos (e.g. Gray dan Elliot 2009, Kaiser dan Groot 2000) dan habitat lamun. Sebagian besar jenis makrozoobenthos yang tidak bernilai ekonomis dibuang ke laut, mencapai $50 \%$ biota tersebut dibuang sebagai discard. Trawl juga telah merambah hingga pada habitat gunung laut dalam (sea mount) yang kaya biodiversity laut dalam yang rentan dan sangat sulit pemulihan ekosistemnya (Koslow et al. 2000 dalam Gray dan Elliot 2009). Pada sedimen berlumpur (muddy sand) saja memerlukan waktu hingga 40 bulan (3,3 tahun) untuk pemulihan ekosistem benthos akibat alat tangkap trawl dasar. Bahkan Allen dan Clarke (2007) dengan simulasi modeling mengestimasi pemulihan ekosistem benthos akibat trawlmemerlukan waktu hingga 5 tahun (Gray dan Elliot 2009).

Dampak kerusakan habitat akibat alat tangkap ditentukan oleh jenis alat tangkap dan kondisi habitat. Bahkan bubu yang dikenal sebagai alat tangkap yang ramah lingkungan sering dioperasikan dengan cara menggali dan merusak terumbu karang. Begitu juga berbagai penangkapan ikan hias karang dengan menggunakan berbagai bahan kimia beracun seperti Sodium cyanide telah merusak terumbu karang secara luas.

Disamping itu kegiatan penangkapan ikan juga berpotensi mencemari lingkungan seperti besarnya bycatch yang dibuang ke dasar perairan (offal), alat tangkap yang dibuangatau hilang, limbah dari pengolahan ikan di atas kapal, serta limbah lainnya dari kapal ikan yang beroperasi di laut. Alat tangkap yang dibuang atau hilang saat operasi penangkapan di samping mencemari perairan, juga masih dapat menangkap ikan atau biota lainnya dikenal sebagai ' $g$ host fishing'. Banyak jaring dengan panjang ratusan kilometer terbuang ke perairan laut merupakan sumber pencemar plastik (marine plastic debris). Sebagai contoh, selama periode dua tahun saja, sekitar 32.000 bubu untuk menangkap rajungan hilang di Teluk Bristol, Alaska (Goñi 1998).

\section{Degradasi struktur ekosistem}

Secara ekologis, penangkapan berdampak langsung atau tidak langsung terhadap perubahan struktur dan fungsi ekosistem. Ekosistem merupakan hubungan fungsional antara komponenkomponen penyusunnya (biotik dan abiotik) pada suatu area ekologis tertentu. Perubahan struktur ekosistem secara mendasar diindikasikan dengan parameter: jumlah jenis (species), kelimpahan (jumlah individu), jumlah biomassa, dan struktur genetik biota. Parameter struktur ekosistem ini merupakan input dalam menentukan nilai biodiversitas suatu ekosistem. Dalam hal ini parameter indeks diversitas, seperti indeks Shannon-Wiener $\left(\mathrm{H}^{\prime}\right)$ telah digunakan secara luas untuk mengevaluasi perubahan 
struktur ekosistem, termasuk yang diakibatkan oleh penangkapan. Fungsi Shannon-Wiener ini diformulasikan sebagai berikut (Krebs 1989):

$$
H^{\prime}=\sum_{i=1}^{S} \frac{n_{i}}{N} x \log _{2} \frac{n_{i}}{N}
$$

dimana:

$H^{\prime}=$ indeks diversitas Shannon-Wiener

$n_{i}=$ jumlah individu spesies ke-i

$N=$ jumlah total individu semua spesies

$S$ = jumlah total spesies yang dianalisis (dalam analisis ini dapat menggunakan Logaritma berbasis 2, 10 , atau e $(\ln ))$

Dalam perkembangannya untuk menganalisis keragaman hasil tangkapan pada suatu wilayah penangkapan atau suatu alat tangkap, dimana data yang tersedia berbasis bobot (biomassa) hasil tangkapan, seperti pada statistik perikanan, maka dapat dimodifikasi sebagai berikut (e.g. Taurusman 2011). Namun hasil ini tidak merefleksikan kualitas suatu ekosistem, namun hanya menggambarkan keragaman hasil tangkapan (Taurusman 2011, Silvano dan Begossi 2001).

$$
H^{\prime}=\sum_{i=1}^{S} \frac{b_{i}}{B} x \log _{2} \frac{b_{i}}{B}
$$

dimana:

$H^{\prime}=$ indeks diversitas Shannon-Wiener

$b_{i}=$ jumlah biomassa spesies ke-i

$B=$ jumlah total biomassa semua spesies

$S$ = jumlah total spesies yang dianalisis.

\section{Degradasi fungsi ekosistem}

Sementara itu, perubahan fungsi ekosistem sebagai dampak penangkapan diindikasikan dengan perubahan parameter kapasitas reproduksi dan interaksi biologi atau rantai makanan. Degradasi jaring makanan akibat penangkapan atau 'fishing down the food webs' yang dicetuskan oleh Daniel Pauly dkk. dan dipublikasi pada Journal Science Vol. 279 tahun 1998 menjadi topik yang mendapat tanggapan luas dari komunitas ilmuwan perikanan global, hingga Februari 2010 saja telah mendapat 947 sitasi pada database Scopus dan 1580 sitasi pada Google Scholar, serta pada 25 sitasi per tahun untuk Journal Science (Christensen dan Maclean 2011).

'Fishing down the food web' (FDFW) merupakan parameter dampak penangkapan terhadap fungsi ekosistem, penurunan struktur rantai makanan (trophic level) dan aliran energi (energy flow) dalam ekosistem. Dengan menggunakan data tangkapan yang dipublikasi secara rutin oleh FAO dan tingkat trofik (trophic level) tangkapan tersebut, maka konsep ini menyimpulkan bahwa rata-rata tingkat trofik tangkapan global telah menurun secara signifikan sebesar 0.5 TL selama periode 50 tahun (1950-1994). Hal ini berarti bahwa akibat penangkapan telah terjadi perubahan secara gradual hasil tangkapan global dari kelompok jenis ikan yang berumur panjang (long-lived), trophic level tinggi, piscivorous dasar menurun menjadi kelompok jenis yang umur pendek (short-lived), trophic levelyang rendah, invertebrata, dan ikan pelagis planktonvora, seperti yang diilustrasikan pada Gambar 2. Ketidakseimbangan ekosistem ini akan mengancam keberlanjutan sumberdaya ikan secara ekologis dan ekonomis. Indikator berbasis TL ini juga kemudian disepakati oleh CBD (the Conference of the Parties to the Convention on Biological Diversity) sebagai indikator kunci untuk mengukur perubahan biodiversitas, dikenal sebagai 'Marine Trophic index' (MTI). 


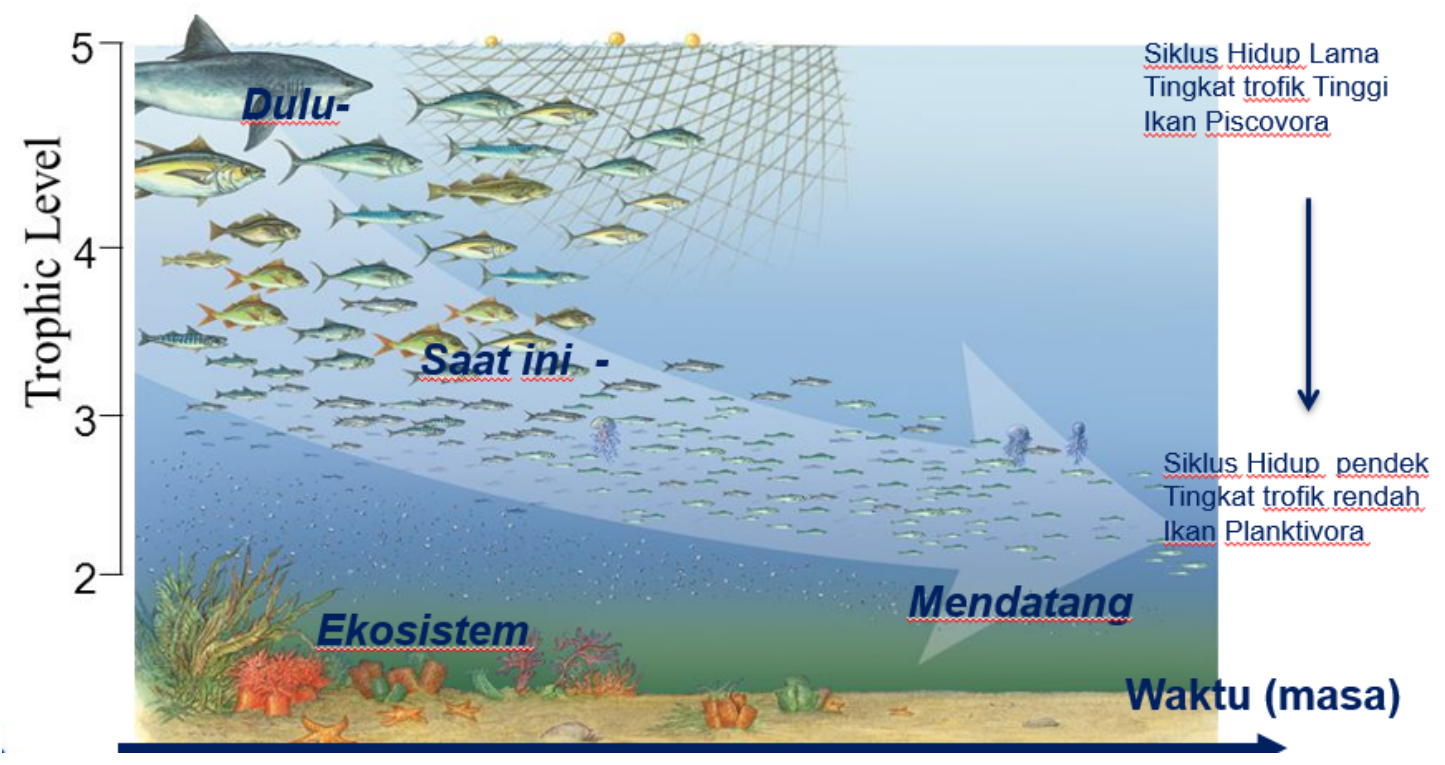

Gambar 2 Ilustrasi Model Fishing Down The Marine Food Webs (Pauly et al. 1998) berikut ini:

Untuk mengestimasi perubahan rata-rata tingkat trofik (trophic level) digunakan persamaan

$$
T L_{m}=\frac{\sum_{i=1}^{S}\left(T L_{i j} \times Y_{i j}\right)}{\sum Y_{i j}}
$$

dimana:

$T L_{m}=$ rata-rata tingkat trofik tangkapan tahunan,

$T L_{i j}=$ tingkat trofik jenis ikan ke-i dalam tahun ke-j,

$Y_{i j}=$ bobot hasil tangkapan spesies ke-i pada tahun ke-j

Dalam perkembangannya, terjadi berbagai diskusi ilmiah yang mengevaluasi konsep FDFW ini. Beberapa ilmuan ekologi laut dan perikanan mencoba mengkritisi konsep ini dengan alasan utama: (a) data tangkapan perikanan komersial atau landing (statistik FAO) yang digunakan sebagai dasar teori ini memiliki banyak kelemahan terkait ketersediaan dan kualitas data, karena tidak semua hasil tangkapan didaratkan (bycatch) atau dilaporkan; (b) tingkat trofik setiap spesies dipengaruhi faktor biologi fase ikan (juvenile atau dewasa), dan lingkungan. Sehingga berkembang konsep 'fishing through', bahkan 'fishing up' (expansion) food webs. Oleh karena itu, kelompok ilmuan ekologi laut seperti Shannon et al. (2014) merekomendasikan bahwa data TL berbasis landing perlu dilengkapi dengan data TL berbasis survey dan berbasis model agar indikator berbasis TL ini dapat merefleksikan dampak penangkapan pada tingkat komunitas ekosistem laut dan 'ecosystem overfishing'. Selanjutnya perlu mempertimbangkan perkembangan kegiatan perikanan (fishing drivers) di suatu wilayah penangkapan, serta pertimbangan ahli bidang marine ecology dalam kerangka ecosystem-based fisheries management.

\section{Faktor-faktor Besarnya Dampak Penangkapan Terhadap Ekosistem}

Besarnya dampak suatu kegiatan penangkapan ditentukan oleh faktor-faktor teknologi alat tangkap yang digunakan dan karakateristik ekologis suatu fishing ground. Secara sistimatis disajikan pada Gambar 3 berikut. 


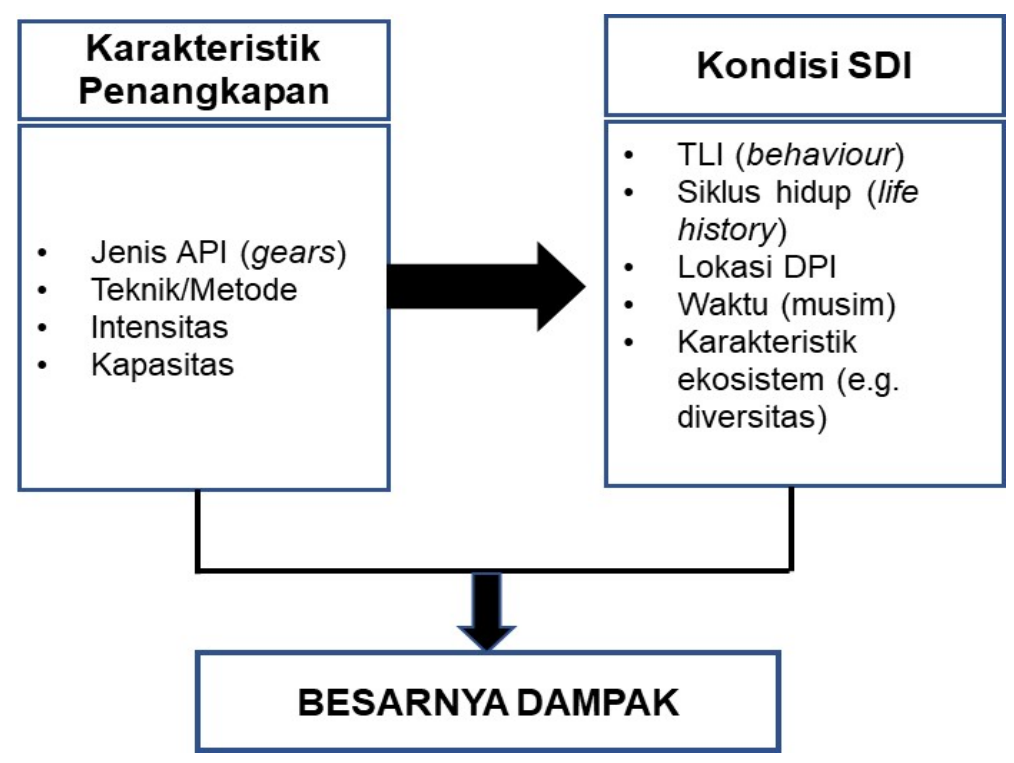

Gambar 3 Interaksi Faktor Karakteristik Penangkapan dan Kondisi Sumberdaya Ikan Menentukan Besarnya Dampak Penangkapan Terhadap Ekosistem

\section{Tingkah laku ikan (behaviour)}

Tingkah laku ikan dan siklus hidup menentukan tingkat kerentanan (vurnerability) suatu spesies (populasi) terhadap kegiatan penangkapan. Tingkah laku ikan sejak lama telah digunakan oleh nelayan untuk menangkap ikan secara efektif dan ekonomis. Ikan-ikan pelagis kecil bersifat bergerombol (shoaling) menguntungkan mereka untuk mencari makan dan menghindari predator. Namun hal ini mengakibatkan kelompok jenis ikan ini lebih mudah ditangkap oleh nelayan. Penangkapan schooling ikan akan lebih menguntungkan nelayan secara ekonomis. Hal ini menyebabkan kelompok ikan dengan tingkah laku seperti ini rentan mengalami kematian akibat penangkapan. Begitu juga, kecepatan renang dan kemampuan ikan untuk menghindari alat tangkap relatif mengurangi kerentanannya akibat penangkapan. Ikan pelagis besar yang bermigrasi jauh, seperti tuna relatif lebih sulit ditangkap, sehingga kurang rentan akibat penangkapan. Kelompok jenis ikan yang hidup di dasar perairan dangkal, seperti teripang dan kerang sangat mudah ditangkap oleh nelayan, sehingga menjadi rentan akibat penangkapan. Pengetahuan tentang tingkah laku ikan ini saat ini banyak digunakan untuk mencegah kematian biota yang dilindungi sebagai dampak sampingan (incidental catch), seperti penyu.

\section{Sejarah kehidupan (life history)}

Keberadaan jenis ikan di alam telah mengalami proses evolusi yang panjang. Jenis yang dapat bertahan adalah yang mampu beradaptasi dengan kondisi lingkungan alam. Hal ini bisa terlihat tingginya keragaman jenis biota yang terdapat di perairan tropis dibandingkan daerah sub-tropis. Intensitas penangkapan ikan mengakibatkan ancaman keberadaan jenis ikan yang ada. Secara teoritis (e.g. Reynolds et al. 2001) jenis ikan yang lambat mencapai umur matang gonad (late maturity), tumbuh lambat (slow growth), ukuran tubuh yang besar (large body size), dan laju peningkatan populasi yang rendah akan menurun lebih cepat populasinya dibandingkan dengan jenis ikan yang relatif cepat ( 'faster' life histories). Jenis ikan tumbuh lambat ini umumnya juga merupakan kelompok ikan pada tingkat trofik yang tinggi pada rantai makanan (karnivora). Kelompok ikan kerapu (famili Serranidae) dan kakap (Lutjanidae) bersifat lebih rentan akibat penangkapan dibandingkan jenis ikan seperti jenis baronang (Siganidae). Umumnya jenis ikan yang bersifat 'late' life history ini memiliki nilai ekonomis yang tinggi dan rasanya yang lebih enak. Sehingga lebih banyak diburu oleh nelayan. Akibatnya kelompok jenis ini lebih rentan terhadap dampak penangkapan. 
Laju pertumbuhan dengan parameter $\mathrm{K}$ dan ukuran pertama matang gonad (length at first maturity) dengan parameter Lm pada persamaan pertumbuhan von Bertalanffy sering digunakan untuk mengevaluasi dampak penangkapan terhadap kelompok jenis ikan berdasarkan parameter alami ini. Tingkat kerentanan berbagai jenis ikan telah dipublikasi secara regular oleh Froese dan Pauly (2020) pada metadata fishbase.org untuk ikan kelompok ikan (fishes) dan biota laut lainnya pada Sealifebase.org. Untuk ikan kakap merah (Lutjanus malabaricus) misalnya, dikategorikan sebagai jenis yang memiliki kerentanan yang tinggi terhadap penangkapan karena diperlukan waktu yang relatif lama yaitu 4,5-14 tahun untuk mencapai jumlah dua kali jumlah populasi yang ada saat ini (minimum population doubling time), dibandingkan dengan ikan baronang garis (Siganus javus) yang hanya memerlukan waktu sekitar 15 bulan. Sehingga dalam pengelolaan perikanan, pengetahuan tentang dampak penangkapan pada berbagai karakteristik jenis ikan akan menentukan tindakan pengelolaan. Strategi pemanfaatan (harvest strategy) untuk perikanan kakap harus lebih lebih hati-hati jika dibandingkan pada perikanan baronang.

Kondisi ekologis suatu daerah penangkapan ikan (fishing ground), waktu (musim) penangkapan mempengaruhi besarnya dampak suatu kegiatan penangkapan terhadap sumberdaya ikan. Penangkapan ikan yang dilakukan pada habitat terumbu karang dan lamun lebih besar dampaknya dibandingkan pada perairan terbuka (off-shore), begitu juga pada perairan laut dalam. Penangkapan yang dilakukan pada musim ikan memijah akan berdampak lebih besar terhadap keberlanjutan ikan target jika dibandingkan pada musim lainnya.

\section{Solusi Teknologi dan Tindakan Manajemen}

Dampak penangkapan terhadap ekosistem dapat dicegah dan kalau sudah terjadi dapat dilakukan upaya perbaikan stok, habitat atau ekosistem. Namun upaya perbaikan (recovery) ini biasa sulit, perlu waktu dan biaya yang besar. Pada Tabel 1 berikut ini disajikan beberapa alternatif teknologi dan tindakan pengelolaan dengan pendekatan EAFM (ecosystem approach to fisheries management) untuk tujuan tersebut pada berbagai jenis dampak penangkapan. Hal ini dihasilkan berdasarkan berbagai analisis referensi antara lain FAO (2003), Gabriel et al. (2005).

Tabel 1 Berbagai Tindakan Pengelolaan Untuk Mencegah dan Mengatasi Dampak Penangkapan Terhadap Ekosistem

\begin{tabular}{|c|c|c|c|c|}
\hline No & Tindakan Pengelolaan & Ikan Target & Bycatch & $\begin{array}{c}\text { Habitat } \\
\text { (lingkungan) }\end{array}$ \\
\hline 1 & Perbaikan teknologi & $\begin{array}{l}\text { Modifikasi API, } \\
\text { selektivitas API, } \\
\text { ukuran API, } \\
\text { modifikasi teknik } \\
\text { penangkapan, DPI, } \\
\text { open-closed system }\end{array}$ & $\begin{array}{l}\text { Modifikasi API, } \\
\text { selektivitas } \\
\text { ukuran \& jenis } \\
\text { API (e.g. TEDs, } \\
\text { umpan), teknik } \\
\text { penangkapan, } \\
\text { zonasi DPI }\end{array}$ & $\begin{array}{l}\text { Pengendalian DPI, } \\
\text { material API yang } \\
\text { mudah terurai } \\
\text { (biodegradable), } \\
\text { MPA, zonasi DPI, } \\
\text { pelarangan trawl, } \\
\text { efisiensi mesin } \\
\text { kapal dan } \\
\text { pengendalian } \\
\text { limbah }\end{array}$ \\
\hline 2 & $\begin{array}{l}\text { Pengendalian input dan } \\
\text { output }\end{array}$ & $\begin{array}{l}\text { Pengendalian } \\
\text { kapasitas (capacity) } \\
\text { dan upaya (effort) } \\
\text { penangkapan, } \\
\text { kuota, ukuran } \\
\text { tangkapan yg } \\
\text { diizinkan }\end{array}$ & $\begin{array}{l}\text { Jenis dan ukuran } \\
\text { tangkapan yang } \\
\text { diizinkan }\end{array}$ & $\begin{array}{l}\text { Pengendalian izin } \\
\text { lokasi DPI }\end{array}$ \\
\hline
\end{tabular}




\begin{tabular}{|c|c|c|c|c|}
\hline No & Tindakan Pengelolaan & Ikan Target & Bycatch & $\begin{array}{c}\text { Habitat } \\
\text { (lingkungan) }\end{array}$ \\
\hline 3 & $\begin{array}{l}\text { Manipulasi ekosistem } \\
\text { (ecosistem manipulation) }\end{array}$ & $\begin{array}{l}\text { Restocking dan } \\
\text { pengayaan stok } \\
\text { secara integrasi }\end{array}$ & - & $\begin{array}{l}\text { Habitat proteksi, } \\
\text { rehabilitasi, dan } \\
\text { habitat buatan }\end{array}$ \\
\hline 4 & $\begin{array}{l}\text { Pendekatan pengelolaan } \\
\text { berbasis hak (rights-based) }\end{array}$ & $\begin{array}{l}\text { Hak wilayah } \\
\text { (TURFs) untuk } \\
\text { sedentary species } \\
\text { dan multi-gears, } \\
\text { hak upaya (effort } \\
\text { right) kalau data } \\
\text { terbatas, hak } \\
\text { penangkapan } \\
\text { (catch right) utk } \\
\text { pelagis besar) }\end{array}$ & - & $\begin{array}{l}\text { Hak wilayah } \\
\text { (TURFs) untuk } \\
\text { sedentary species } \\
\text { dan multi-gears }\end{array}$ \\
\hline
\end{tabular}

Keterangan: API = alat penangkapan ikan, TEDs (turtle excluder devices), DPI = daerah penangkapan ikan, MPA (Marine protected area), kawasan perlindungan laut, TURFs = territorial use rights in fisheries

\section{KESIMPULAN DAN SARAN}

Berdasarkan analisis dapat disimpulkan bahwa kegiatan penangkapan berdampak terhadap ikan target, non-target (bycatch), serta habitat (lingkungan). Indikator dampak penangkapan terhadap ekosistem adalah degradasi populasi (kematian) ikan target dan non-target, degradasi (kerusakan) fisik habitat, dan pencemaran lingkungan perairan. Secara ekologis merupakan parameter struktur ekosistem (jumlah jenis, kelimpahan, biomassa) dan fungsi ekosistem (reproduksi dan rantai makanan). Besarnya dampak penangkapan pada suatu ekosistem ditentukan oleh karakteristik kegiatan penangkapan dan kondisi suatu sumberdaya ikan. Dampak penangkapan merupakan basis utama dalam pengelolaan perikanan berkelanjutan (EAFM). Opsi tindakan pengelolaan perikanan (fisheries management measures) untuk mengatasi dampak penangkapan berupa perbaikan teknologi penangkapan, pengendalian input dan output, manipulasi ekosistem, dan pengelolaan berbasis hak (right-based).

\section{UCAPAN TERIMA KASIH}

Penulis pengucapkan terima kasih kepada teman sejawat (kolega) dosen dan mahasiswa pada Departemen PSP, FPIK IPB khususnya mahasiswa bimbingan tugas akhir penulis AAT yang telah membantu dalam menganalisis, menerapkan, serta aktif mendiskusikan konsep dampak penangkapan terhadap ekosistem dan pengelolaan perikanan berkelanjutan (EAFM) yang mendasari dan menginspirasi kajian ini penting diwujudkan.

\section{DAFTAR PUSTAKA}

Allen JI, Clarke KR. 2007. Effect of demersal trawling on ecosystem functioning in the North Sea: a modelling study. Marine Ecology Progress Series 336: 63 - 75

Almodhar E, Baskoro MS, Yusfiandayani R, Taurusman AA. 2013. Dampak penangkapan terhadap struktur dan tingkat trofik hasil tangkapan ikan di Perairan Maluku Tenggara. Jurnal Teknologi Perikanan dan Kelautan 4 (2): 131-138 
Christensen V, Maclean J. 2011. Ecosystem Approach to Fisheries. Cambridge University Press. UK

[FAO] Food and Agriculture Organization. 1997. A Study of the Options for Utilization of Bycatch and Discards from Marine Capture Fisheries. FAO Rome.

[FAO] Food and Agriculture Organization. 2003. Fisheries Management: the Ecosystem Approach to Fisheries. FAO Technical Guideline for Responsible Fisheries. FAO, Rome.

Froese R, Pauly D. (Eds.). 2020. Fishbase. World Wide Web electronic publication. Tersedia pada www.fishbase.org, version 12/2019. [Diakses 20 Juni 2020]

Gabriel O, Lange K, Dahm E, Wendt T (eds.). 2005. Von Brand's Fish Catching: Methods of the World. Fourth Edition. Blackwell Publishing. Oxford, UK.

Gray JS, Elliott M. 2009. Ecology of Marine Sediments: From Science to Management. Second edition. Oxford University Press. Oxford, UK.

Goñi R .1998. Ecosystem effects of marine fisheries: an overview. Ocean and Coastal Management 40: 37-64

Jennings S, Kaiser MJ, Reynolds JD. 2001. Marine Fisheries Ecology. Blackwell Publishing. Oxford, UK

Jennings S, Keiser MJ. 1998. The effects of fishing on marine ecosystem. Advances in Marine Biology 34: $201-352$

Kaiser J, de Groot SJ. 2000. Effect of Fishing on Non-Target Species and Habitats: Biological, Conservation and Socio-Economic Issues. Blackwell Science Ltd. Oxford, London, Edinburg, UK.

Krebs CJ. 1989. Ecological Methodology. Harper and Row, Newyork. USA.

Pauly D, Christensen V, Dalsgaard J, Froese R, Torres Jr F. 1998. Fishing down marine food webs. Science 279: 860-863.

Pauly, D. 2010. Five (5) Easy Pieces: Fishing Impacts Marine Ecosystem. Island Press, Washington DC, USA.

Shannon L, Coll M, Bundy A, Gascuel D, Heyans JJ, Kleisner K, Lynam CP, Prioddi C, Tam J, TraversTrolet M, Shin Y. 2014. Trophic level-based indicators to track fishing impact across marine ecosystem. Marine Ecology Progress Series. Vol. 512: 115-140.

Stergiou KI, Moutopoulos DK, Casal HJA, Erzini K. 2007. Trophic signature of small - scale fishing gears: implication for conservation and management. Marine Ecology Progress Series. Vol. 333: 117-128.

Silvano RAM, Begossi A. 2001. Seasonal dynamics of fishery at Piracicaba River (Brazil). Fisheries Research Journal. No. 51: 69-86.

Stergiou KI, Tsikliras AC. 2011. Fishing down, fishing through and fishing up: fundamental process versus technical details. Marine Ecology Progress Series. Vol. 441: 295-301.

Taurusman AA. 2011. Pengujian indikator ekologis perikanan berkelanjutan: struktur komunitas hasil tangkapan ikan di Kabupaten Kotabaru, Kalimantan Selatan. Buletin PSP. Vol. XIX No.1: 1-12. ISSN: 0251-286X.

Taurusman AA, Firdaus D, Martasuganda S, Yulianto I, Nurani TW, Agustina S. 2018. Ecological impact of Siganid fishery on target and trophic level in Kepulauan Seribu water, Presented on International Biology Conference the 4th IBOC, ITS Surabaya. 